\title{
In vitro evaluation of prebiotic properties derived from rice bran obtained by debranning technology
}

Premsuda Saman ${ }^{1,2}$, Kieran M. Tuohy ${ }^{3}$, José A. Vázquez $^{4^{*}}$, Glenn Gibson ${ }^{5}$, and Severino S. Pandiella ${ }^{2}$

${ }^{1}$ Bioscience Department, Thailand Institute of Scientific and Technological Research

35 Moo 3 Technopolis, Khlong 5, Khlong Luang, Pathumthani 12120 Thailand

${ }^{2}$ School of Chemical Engineering and Analytical Science, The University of Manchester. Sackville Street, PO Box 88, Manchester M60 1QD, UK

${ }^{3}$ Department of Food Quality and Nutrition, Research and Innovation Centre, Fondazione Edmund Mach (FEM), Via Mach 1, San Michele all'Adige, TN, Italy

${ }^{4}$ Group of Recycling and Valorization of Waste Materials (REVAL). Marine Research Institute (IIM-CSIC), R/ Eduardo Cabello 6, CP36208, Vigo, Spain

${ }^{5}$ Department of Food Biosciences, School of Chemistry, Food Bioscience and Pharmacy, University of Reading, Reading RG6 6AP, UK

*Corresponding author Dr José A. Vázquez Tel +34 986214468

Email: jvazquez@iim.csic.es

An abbreviated running headline: prebiotic potential of rice fractions 


\begin{abstract}
The prebiotic ability of several rice bran fractions obtained by debranning (RBD) using human microbiota was studied in anaerobic batch cultures with agitation and $\mathrm{pH}$-controlled. Fraction $\mathrm{C}(3.8-5 \% \mathrm{w} / \mathrm{w}$ pearling) from RBD increased the number of bifidobacteria and lactobacteria compared with the positive control, raftilose P95. RBD fermentation induced changes in the short-chain fatty acid (SCFA) profile. In addition, Fraction $\mathrm{C}$ revealed the highest growth of positive lactobacteria than commercial control. The present work illustrates the prebiotic capacity of RBD to modulate human microbiota and highlights that fraction $\mathrm{C}$ could be an economical source for use in human food as well as an interesting alternative to valorize a by-product of cereal industry.
\end{abstract}

Keywords: rice bran; debranning; batch cultures; prebiotic; human microbiota. 


\section{Introduction}

Rice bran derived from the outer layer of the rice grain is one of the most abundant, underutilised co-products (Brunschwiler et al., 2013; Sharp, 1991; Vergara, 1991). Rice bran is an important source of dietary fibres such as soluble fibre and insoluble fibre (arabinoxylans, hemicellulose, lignin, $\beta$ glucans). These polysaccharides can resist digestion and absorption in the upper human gut and enter the colon, where they undergo fermentation by the colonic microbiota. The consequences of fermentation by the gut microbiota include increased faecal bulk through bacterial proliferation and the formation of microbial metabolites, for example, short-chain fatty acids and gas (Álvarez \& Sánchez, 2006; Beards et al., 2010; Cummings \& Macfarlane, 1991). Dietary fibre has been shown to improve health and prevent diseases, with the more soluble, viscous, and fermentable fibre sources being proposed to reduce the glycemic index, insulin sensitivity (Hallfrisch \& Behall, 2000) and cholesterol absorption (Kahlon et al., 1994).

There are many studies focusing on the prebiotic potential of cereal bran products (Berger et al., 2014; Kedia et al., 2009; Yang et al., 2014). A prebiotic is a "nondigestible food ingredient that affects the host by selectively targeting the growth and/or activity of one or a limited number of bacteria in the colon, and thus has the potential to improve host health". This is currently accepted as including increases in the populations of Bifidobacterium spp. and Lactobacillus spp., as both genera are viewed as positive for host health and have a long history of use as probiotics (Hughes et al., 2007). A number of methods have been used to evaluate the prebiotic properties of a potential substrate 
(Costabile et al., 2016; Costabile et al., 2015; Likotrafiti et al., 2014; Sarbini et al., 2014). For a rapid comparative evaluation, batch fermentation vessels inoculated with faecal slurries are useful as they represent the diverse gut microflora (Connolly et al., 2010; Gómez et al., 2010; Likotrafiti et al., 2014). In addition, several vessels can be set up simultaneously. They can be used on a small scale for screening potential substrates which are only available in small quantities and the process is completed within $24 \mathrm{~h}$ (Rycroft et al., 2001). The method of fluorescent in situ hybridisation (FISH) is used for the rapid and specific identification of individual microbial cells. FISH is the genetic technique whereby genus-specific fluorescently labelled oligonucleotide probes are hybridised to bacterial rRNA extracted from a faecal or a fermentation sample. The resultant fluorescently labelled cells are then enumerated by fluorescence microscopy (McCartney, 2002).

Many researches are attempting to focus on phytonutrients in rice bran (Ardiansyah et al., 2006; Cai et al., 2005; Godber \& Wells, 1994; Jariwalla, 2001; Ogué-Bon et al., 2011). Some studies have developed strategies to improve the functional properties of rice bran (Lee et al., 2014; Saman et al., 2011). However, none reported on the effect of pearling on the prebiotic level in bran fractions. Identifying the layers of bran containing the majority of prebiotics would be helpful in maximising the economics of efficiently extracting these compounds. Therefore, this study provided information regarding prebiotic properties within the rice kernel based on bran collected from different degrees of debranning. A small-scale faecal batch culture representing the human gut was used in the experiment. The fermentability and bifidogenic activity of 
different rice bran fractions was monitored by bacteria enumeration using FISH method. SCFA production was also determined by gas chromatography.

\section{Methods}

\section{Rice bran fraction preparation}

The paddy rice RD6 (glutinous rice cultivar from Sisaket, Thailand) was initially dehusked using a laboratory dehusker (THU35A, Satake, Japan). Samples (200 g, moisture content 12\%) were pearled with a test mill (Model TM05, Satake Engineering Co, Japan) using an abrasive wheel (sieve size no. 40) rotating at $1450 \mathrm{rpm}$ to obtain rice fractions. The weight percentage of rice layers removed by pearling was calculated from the weight of rice before and after pearling (Lamberts et al., 2007). The pearling fractions obtained after 5, 10, 20, 30, $40 \mathrm{~s}$ and the residual kernels were labelled as fractions $A, B, C, D, E$ and $F$ respectively.

\section{Chemical analysis}

Total fibre, soluble fibre and insoluble fibre were measured according to the method of Prosky et al. (1992). The concentration of soluble free amino nitrogen (FAN) during fermentation was assayed by the EBC-ninhydrine colorimetric method (European-Brewery-Convention, 1973). The concentration of total reducing sugars (TRS) was determined by following the method of Miller (1959), using 3,5-dinitrosalicylic acid solution. 


\section{Fermentation monitoring}

Batch culture fermentations

The method for batch culture fermentation was modified from that of Mandalari et al. (2007). The $300 \mathrm{ml}$ water-jacketed fermenters were filled with $180 \mathrm{ml}$ presterilised basal growth medium at $\mathrm{pH}$ 7.0. The fermenters were inoculated with $20 \mathrm{ml}$ of faecal slurry. This faecal slurry was prepared by homogenizing $10 \%(\mathrm{w} / \mathrm{v})$ fresh faeces from a healthy donor, who had not taken antibiotics for 3 months beforehand, in $0.1 \mathrm{M}$ phosphate buffered saline (Oxoid), $\mathrm{pH}$ 7.0. Each 2 $\mathrm{g}$ rice fraction was added to give a final concentration of $1 \%(\mathrm{w} / \mathrm{v})$ and $2 \mathrm{~g}$ of raftilose P95 (95\% fructo-oligosaccharides) was used as a positive control. Each vessel was magnetically stirred with temperature controlled at $37^{\circ} \mathrm{C}$ by circulating water bath (Type GD120, Grant Instruments, UK). Culture pH was controlled at $\mathrm{pH}$ 6.6-6.8 by a pH controller (model 260 Electrolab, UK). Anaerobic conditions were maintained by sparging the vessels with oxygen-free nitrogen gas at $15 \mathrm{ml} / \mathrm{min}$. Samples $(5 \mathrm{ml})$ were taken from the fermenters at the start and at intervals over a 24-h incubation period. The fermentation experiments were performed in triplicate for each substrate using faecal inoculum from three volunteers.

\section{Enumeration of bacteria}

Bacteria were counted using FISH as described by Daims et al. (2005) and Rycroft et al. (2001). Samples were fixed overnight at $4^{\circ} \mathrm{C}$ with $4 \%(w / v)$ filtered paraformaldehyde $(\mathrm{pH} 7.2)$ in a ratio of $1: 3(\mathrm{v} / \mathrm{v})$. Samples were washed twice with filtered phosphate buffered saline $(0.1 \mathrm{M}, \mathrm{pH} 7.0)$, and stored at $-20^{\circ} \mathrm{C}$ in PBS/ethanol (1:1 v/v) until further processing. When required for counting, the 
fixed cells were hybridised with the appropriate genus-specific probes for differential bacterial counts, or 4,6-diamidino-2- phenylindole (DAPI) for total cell counts. The probes used consisted of Bif 164 for Bifidobacterium spp. (Langendijk et al., 1995), His 150 specific for Clostridium histolyticum subgroup (Franks et al., 1998), Bac 303 specific for Bacteroides spp. (Manz et al., 1996), Erec 482 specific for Clostridium coccoides-Eubacterium rectale group (Franks et al., 1998), Ato 291 specific for Atopobium spp. and Lab 158 specific for Lactobacillus IEnterococcus spp. (Harmsen et al., 1999; Harmsen et al., 2002).

Short-chain fatty acid (SCFA) analysis

The method was carried out as described by Zhao et al. (2006). The $300 \mu \mathrm{l}$ of sample solution was acidified by adding $100 \mu \mathrm{l}$ of $6 \mathrm{M} \mathrm{HCl}$ and left at room temperature for $10 \mathrm{~min}$. The suspension was centrifuged at 13,793 $\mathrm{g}$ (Centrifuge model 5402, Eppendorf, West Germany) for 10 min, giving a clear supernatant and filtrated through $0.22 \mu \mathrm{m}$ PVDF Whatman filter. Then, $100 \mu \mathrm{l}$ of the internal standard, $10 \mathrm{mM}$ ethylbutyric acid solution, were added into $400 \mu \mathrm{l}$ of the filtered supernatant. The supernatant was finally injected in the GC (model 5890 Series II, Hewlett Packard, USA) under specific conditions. The column was an FFAP column $(30 \mathrm{~m} \times 0.53 \mathrm{~mm}$ diameter $0.50 \mu \mathrm{m}, \mathrm{J} \& \mathrm{~W}$ Scientific, USA). Helium was used as the carrier gas with a flow rate of 14 $\mathrm{ml} / \mathrm{min}$. The head pressure was set at $10 \mathrm{psi}$ and the split ratio is $10: 1$. The total flow is $140 \mathrm{ml} / \mathrm{min}$. The initial oven temperature was $100^{\circ} \mathrm{C}$, maintained for 0.5 min, raised to $150^{\circ} \mathrm{C}$ at $8^{\circ} \mathrm{C} / \mathrm{min}$, then increased to $250^{\circ} \mathrm{C}$ at $50^{\circ} \mathrm{C} / \mathrm{min}$, and finally held at $250^{\circ} \mathrm{C}$ for $2 \mathrm{~min}$. The temperatures of the injector and the detector were set at $280^{\circ} \mathrm{C}$ and $300^{\circ} \mathrm{C}$ respectively. The injected volume was $1 \mu \mathrm{l}$ and 
the runtime was 10.75 min. Concentrations of SCFA were determined (in $\mathrm{mM}$ ) and then the areas under the kinetic curves ( $\mathrm{AUC}$, in $\mathrm{mM} \mathrm{h}$ ) were calculated as (Amado et al., 2016):

$$
A \cup C=\left(y_{0}+2 y_{1}+2 y_{2}+\ldots+2 y_{n-2}+2 y_{n-1}+2 y_{n}\right) \frac{\Delta t}{2}
$$

where $y_{0}$ to $y_{n}$ are the $n+1 y$-values defining the curve, and $\Delta t$ is the sampling interval (h).

\section{Statistical evaluations}

Statistical analysis was performed using Windows Excel (Microsoft Corporation). Differences between bacteria numbers and SCFA concentrations at $0,5,10$ and 24 hours of fermentation from each batch culture were checked for significance by paired t test assuming variances and considering both sides of distribution. Univariate analysis of variance (ANOVA) two factors with replication was used to compare the difference between each substrate and positive control in terms of their effects on bacteria population and SCFA production. Differences were significant at $P \leq 0.05$.

\section{Results}

The chemical composition of the different rice fractions obtained by debranning is shown in Table 1 . The highest levels of fiber were observed in $A, B$ and $C$ fractions, and the higher soluble fiber was presented in $B$ and $C$ fractions. The lower fiber presence was detected in $\mathrm{E}$ and $\mathrm{F}$ (endosperm and embryo) that are richest in starch. Highest concentrations of FAN were obtained in $B, C$ and $D$ 
fractions. Seed coat including spermoderm and nucellar layer are the main tissue present in the samples C and D.

In vitro batch culture fermentations were used to investigate the prebiotic activities of rice bran fractions. Samples were taken at intervals in order to monitor the levels of different bacterial groups (Figure 1) and the SCFA production. Results shown in Table 2 indicate that a significant increase in the level of total bacteria was obtained in all batch cultures from $5 \mathrm{~h}$ until $24 \mathrm{~h}$. The number of Bifidobacterium spp. obviously increased, especially in the cultures of rice bran fraction $B, C$, and $D$ compared with the positive control, raftilose P95 oligofructose. This result can be due to the higher content of soluble fiber and protein present in those fractions. Increments of Lactobacillus spp. and Entercococcus spp. were slightly and observed in each culture. In addition, a significant increase in the number of eubacteria and bacteroides was obtained in batch cultures of rice fraction $E$ and $F$, the latter showing a greater increase. The population of Clostridium histolyticum and Atopobium spp. notably decreased in each culture after faecal inoculation while significant decrease of C. histolyticum in the positive control was observed after $5 \mathrm{~h}$.

When all substrates were compared with positive control in terms of their effects on bacteria population, the results showed that a significant difference in bifidobacterial population was obtained in the culture of rice fraction $F$ while the level of $E$. rectale/C. coccoides was significantly different in cultures of rice fraction A, B and C. The population of C. histolyticum was significantly different 
in cultures of rice fraction D and F. However, the total bacterial population of all cultures was not significantly different.

Significant increase in total SCFA occurred in all substrates, especially in raftilose P95 and rice fraction $\mathrm{F}$. The level of acetic acid increased significantly in all cultures by $24 \mathrm{~h}$, while a significant increase in propionic acid was observed in rice fraction $B$ at $10 \mathrm{~h}$ (data not shown). The concentration of $\mathrm{n}$ butyric acid was significantly increased in both cultures of rice fraction A and F. The level of i-butyric acid, i-valeric acid, n-valeric and n-capronic acid increased slightly in all cultures (data not shown). The global productions of SCFA measured in the fermentations and calculated as AUC (in $\mathrm{mM} \mathrm{h}$ ) are presented in Table 3.

Fraction $\mathrm{F}$ and control showed the higher productions of acetic but the difference were not significant between them and in comparison with the other fractions $(p>0.05)$. Similar descriptions can be defined for the production of propionic acid. Moreover, no significant differences between fractions effects were observed for the fermentative production of $n$-butyric, $n$-valeric and $n$ caprionic $(p>0.05)$. Fractions $A$ and $D$ were statistically the best options for the production of i-valeric and i-butyric, respectively.

The concentration of total SCFA was significantly higher in fraction F followed by raftilose P95 oligofructose and both significantly superiors to the rest of cultures $(p \leq 0.05)$. These findings were confirmed by the ratio acetate:propionate:butyrate at $24 \mathrm{~h}$ displayed in Figure 2. 


\section{Discussion}

This study has shown the prebiotic potential of rice bran fractions with different degrees of debranning. Rice bran generated from a rice milling process contains various nutritional substrates. Doesthae et al. (1979) reported that rice bran constituted approximately $10 \%$ by weight of the whole kernel which consisted of the pericarp, seed coat (with spermoderm and nucellar layers), endosperm including aleurone layer and the embryo or germ.

During initial pearling, the outer layers of the rice kernel, comprised of pericarp, seed coat, and nucellus, are removed. Subsequent pearling removes the more inner layers such as aleurone cells, and the embryo (Juliano and Bechtel, 1985), leaving polished rice, composed mainly of starchy endosperm. The concentrations of chemical components that are concentrated with abundance in the bran layers and the germ of rice have been related to the degree of pearling (Ha et al., 2006; Mohapatra \& Bal, 2006). Among six different rice fractions, fraction A contained mainly the outer layer of rice kernel following by fractions $B, C, D$ and $E$. Fraction $F$ was the remains of the kernel after 40-s pearling consisting mostly endosperm.

To evaluate the prebiotic activity, it is necessary to analyse the evolution of the bacterial populations in the presence of the substrate being tested (Costabile et al., 2016). The behaviour of different bacteria in the fermentation could be monitored in mixed cultures due to synergistic, antagonistic and/or competitive

effects (Mandalari et al., 2007). The fermentation process in the gut is a complex process whereby many metabolic pathways are carried out by different 
groups of bacteria (Gibson \& Roberfroid, 1995; Likotrafiti et al., 2014). Therefore, in this study the rice bran fractions were tested to evaluate the potential prebiotic using mixed faecal cultures. The fermentation conditions were maintained anaerobically at $37^{\circ} \mathrm{C}$ and $\mathrm{pH}$ 6.6-6.8 (Hughes et al., 2007; Rycroft et al., 2001). Raftilose P95 as a source of fructo-oligosaccharides was used as a positive control (Tuohy et al., 2005; Beards et al., 2010).

According to the prebiotic concept, changes of bacterial population could be monitored in both numbers of beneficial bacteria and disadvantageous bacteria (Hughes et al., 2007). The genera Bifidobacterium and Lactobacillus do not contain any known pathogens, and they are primarily carbohydrate-fermenting bacteria in comparison to clostridia. The products of carbohydrate fermentation, principally SCFA are beneficial to host health, while those of protein breakdown and of amino acid fermentation, which include ammonia, phenols, indoles, thiols, amines and sulphides are not healthy (Macfarlane et al., 2006). Eubacteria are involved in the production of butyric acid which is the main fuel for colonic epithelial cells (Pryde et al., 2002), while Atopobium spp. for instance may be considered in specific cases, certain vaginal disorders, as a potential pathogen (De Backer et al., 2006). Thus, an increase in the populations of bifidobacteria, lactobacilli and eubacteria could be used as the indicators.

In the fermentations, a significant increase of total bacteria was found in all cultures. However, the majority of the bifidobacteria and lactobacilli/enterococci grew better on the rice fraction $\mathrm{C}$ compared to the other selected gut bacteria. On the other hand, all of the Bacteroides spp. and C. histolyticum showed very 
low growth on this fraction. This clearly indicates that the rice fraction $\mathrm{C}$ may allow a prebiotic effect by preferentially enhancing the growth of bifidobacteria and reducing the growth of bacteroides and clostridia. This fraction $\mathrm{C}$ is composed by a medium percentage of total fiber among the fractions tested but the highest concentration, together with $\mathrm{B}$, of soluble fiber, FAN and TRS. This fraction $B$ was in fact the substrate in which the second best results were observed. Similar prebiotic capacity was defined by oat bran rich in soluble fiber and FAN (Kedia et al., 2008 and 2009). In this context, rice bran with high contents of dietary fiber showed functional effect as prebiotics in human and canine microbiota (Inness et al., 2011; Kanauchi et al., 2014).

A bifidogenic effect was observed in all cultures of rice fractions except the culture of rice fraction F. In this fraction the levels of FAN, TRS and soluble fiber were certainly poor and it would explain the low prebiotic yield. A small increase in the numbers of lactobacilli/enterococci was also obtained in all cultures. Furthermore, an increase in eubacteria population was obtained in all cultures with the highest cell population in the cultures of rice fraction F. Pryde et al. (2002) reported that the proliferation of eubacteria possibly relates to an increment of butyric acid production. Bacteroides are a metabolically versatile group with respect to their ability to utilise many types of plant polysaccharides as substrates (Hopkins et al., 2003). This correlates with the significant increases in bacteroides observed in response to all rice fractions. However, the increases were modest when compared to those in bifidobacteria. 
Gibson (1998) reported that the main saccharolytic species in the colonic microflora belonged to the genera Bacteroides, Bifidobacterium, Ruminococcus, Eubacterium, Lactobacillus and Clostridium. Carbohydrates that resist digestion and escape absorption in the small intestine are available for colonic bacterial fermentation in the colon resulting in the production of SCFA and a number of other metabolites such as lactate, pyruvate, ethanol, succinate as well as the gases $\mathrm{H}_{2}, \mathrm{CO}_{2}, \mathrm{CH}_{4}$ and $\mathrm{H}_{2} \mathrm{~S}$ (Topping \& Clifton, 2001; Likotrafiti et al., 2014). Butyric acid has been hypothesized to reduce the risk of colon cancer and to benefic inflammatory bowel disease (Floch \& Hong-Curtiss, 2002). Propionate is metabolised in the liver, acting as a precursor in gluconeogenesis and lipogenesis (Velazquez et al., 1996). Acetate is the main SCFA produced and utilised by peripheral tissues (Hijova \& Chmelarova, 2007).

During batch fermentation, various metabolic processes in the anaerobic bacteria took place. The major products of fermentation were SCFA mainly acetate, propionate and butyrate, but n-valerate, n-caproate, i-butyrate and ivalerate were also present. Results in Table 3 and Figure 2 show that the concentrations of SCFA produced from different rice fractions were variable. The highest product of SCFA was acetic acid following by propionic acid and butyric acid respectively. The concentrations of branched SCFA (i-butyric, ivaleric n-valeric and n-capronic) were trace. Hijova \& Chmelarova (2007) reported that in human colon, carbohydrates are fermented by saccharolytic bacteria resulting in the production of linear SCFA (acetic acid, propionic acid and butyric acid) while fermentation of proteins and amino acids by proteolytic bacteria yield branched SCFA. However, in the present case the production of 
SCFA was not concordant with the bifidogenic effect of fractions B and $C$ and the microbial growths associated to these fractions. The fermentations in both fractions led to the lowest concentrations of SCFA in the postincubates and the highest quantity of lactic acid bacteria. In the cultures formulated with raftilose P95 and fraction F the growth of lactic acid bacteria was lower but the counts of total bacteria and the corresponding SCFA productions were greater.

\section{Conclusions}

Fraction C (3.8 to 5\% pearling) has the highest prebiotic potential among all the fractions tested. The degree of pearling clearly influences the prebiotic content of bran in cereals. The prebiotic-rich layer tends to be removed earlier in the milling process since it is primarily located in the bran obtained during the first 30 seconds of pearling (higher content in proteins and soluble fiber). This

suggests that a selected debranning strategy could produce a fraction with a high oligosaccharide content that could be later used to isolate the prebiotic ingredients. Results reveal that this fraction would have a prebiotic effect higher than the one found in commercial prebiotic formulations.

\section{Acknowledgements}

The authors wish to acknowledge the The Royal Thai Government for the grant awarded to Premsuda Saman. The authors acknowledge the support of the European Science Foundation (ESF), in the framework of the Research Networking Programe, The European Network for Gastrointestinal Health Research (ENGIHR). 


\section{Disclosure statement}

The authors declare that there is not conflict of interest

\section{References}

Amado IR, González MP, Murado MA, Vázquez JA. 2016. Shrimp wastewater as a source of astaxanthin and bioactive peptides. J Chem Technol Biotech 91:793-805.

Álvarez EE, Sánchez PG. 2006. Dietary fibre. Nutr Hosp 21:60-71.

Ardiansyaha, Shirakawa H, Koseki T, Ohinata K, Hashizume K, Komai M. 2006.

Rice bran fractions improve blood pressure, lipid profile, and glucose metabolism in stroke-prone spontaneously hypertensive rats. J Agric Food Chem 54:1914-1920.

Beards E, Tuohy K, Gibson G. 2010. Bacterial SCFA and gas profiles of a range of food ingredients following in vitro fermentation by human colonic microbiota. Anaerobe 16:420-425.

Berger K, Falck P, Linninge C, Nilsson U, Axling U, Grey C, Stålbrand H, Nordberg Karlsson E, Nyman M, Holm C, Adlercreutz P. 2014. Cereal byproducts have prebiotic potential in mice fed a high-fat diet. J Agric Food Chem 62:8169-8178.

Brunschwiler C, Heine D, Kappeler S, Conde-Petit B, Nyström L. 2013. Direct measurement of rice bran lipase activity for inactivation kinetics and storage stability prediction. J Cereal Sci 58:272-277.

Cai H, Al-Fayez M, Tunstall RG, Platton S, Greaves P, Steward WP, Gescher AJ. 2005. The rice bran constituent tricin potently inhibits 
cyclooxygenase enzymes and interferes with intestinal carcinogenesis in ApcMin mice. Mol Cancer Ther 4:1287-1292.

Connolly ML, Lovegrove JA, Tuohy KM. 2010. In vitro evaluation of the microbiota modulation abilities of different sized whole oat grain flakes. Anaerobe 16:483-488.

Costabile A, Walton GE, Tzortzis G, Vulevic J, Charalampopoulos D, Gibson GR. 2015. Effects of orange juice formulation on prebiotic functionality using an in vitro colonic model system. PLoS ONE 10:e0121955.

Costabile A, Deaville ER, Morales AM, Gibson GR. 2016. Prebiotic potential of a maize-based soluble fibre and impact of dose on the human gut microbiota. PLoS ONE 11: e0144457.

Cummings JH, Macfarlane GT. 1991. The control and consequences of bacterial fermentation in the human colon. J Appl Microb 70:443-459.

Daims, H., Maixner F, Lücker S, Stoecker K, Hace K, Wagner M. 2005. Fluorescence in situ hybridization for the detection of prokaryotes. In: A. M. Osborn, and Smith, C.J., (Ed.), Molecular microbial ecology. Garland Science, Abingdon, UK, pp. 213-239.

De Backer E, Verhelst R, Verstraelen H, Claeys G, Verschraegen $G$, Temmerman M, Vaneechoutte M. 2006. Antibiotic susceptibility of Atopobium vaginae. BMC Infec Dis 6:1-6.

Doesthale YG, Devara S, Rao S, Belavady B. 1979. Effect of milling on mineral and trace element composition of raw and parboiled rice. J Sci Food Agric 30:40-46.

European-Brewery-Convention. 1973. Ninhydrin method for determination of free a-amino nitrogen. J Inst Brewing 79:37-41. 
Floch MH, Hong-Curtiss J. 2002. Probiotics and functional foods in gastrointestinal disorders. Curr Treat Options Gastroenter 5:311-321.

Franks AH, Harmsen HJ, Raangs GC, Jansen GJ, Schut F, Welling GW. 1998. Variations of bacterial populations in human feces measured by fluorescent in situ hybridization with group-specific 16S rRNA-targeted oligonucleotide probes. Appl Environ Microbiol 64:3336-3345.

Gibson GGR. 1998. Dietary modulation of the human gut microflora using prebiotics. The Brit J Nutr 80:12.

Gibson GR, Roberfroid MB. 1995. Dietary modulation of the human colonic microbiota: introducing the concept of prebiotics. J Nutr 125:1401-1412.

Godber JS, Wells JH. 1994. Rice bran: as a viable source of high value chemical. Louisiana Agric 37:13.

Gomez E, Tuohy KM, Gibson GR, Klinder A, Costabile A. 2010. In vitro evaluation of the fermentation properties and potential prebiotic activity of Agave fructans. J Appl Microb 108:2114-2121.

Ha TY, Ko SN, Lee SM, Kim HR, Chung SH, Kim SR, Yoon HH, Kim IH. 2006. Changes in nutraceutical lipid components of rice at different degrees of milling. Eur J Lipid Sci Tech 108:175-181.

Halffrisch J, Behall KM. 2000. Mechanisms of the Effects of Grains on Insulin and Glucose Responses 19:S320S-325.

Harmsen HJM, Elfferich P, Schut F, Welling GW. 1999. A 16S rRNA targeted probe for detection of lactobacilli and enterococci in faecal samples by fluorescent in situ hybridization. Microb Ecol Health Dis 11:3-12. 
Harmsen HJM, Raangs GC, He T, Degener JE, Welling GW. 2002. Extensive set of 16S rRNA-based probes for detection of bacteria in human feces. Appl Environ Microbiol 68:2982-2990.

Hijova E, Chmelarova A. 2007. Short chain fatty acids and colonic health. Bratisl Lek Listy. 108:354-358.

Hopkins MJ, Englyst HN, Macfarlane S, Furrie E, Macfarlane GT, McBain AJ. 2003. Degradation of cross-linked and non-cross-linked arabinoxylans by the intestinal microbiota in children. Appl Environ Microbiol 69:63546360.

Hughes SA, Shewry PR, Li L, Gibson GR, Sanz ML, Rastall RA. 2007. In vitro fermentation by human fecal microflora of wheat arabinoxylans. J Agric Food Chem 55:4589-4595.

Inness VL, Khoo C, Gross KL, Hoyles L, Gibson GR, McCartney AL. 2011. Use of static batch culture systems to investigate the fermentation effects of selected oligosaccharides and fibres by the canine faecal microbiota. Int J Prob Preb 6:57-64.

Jariwalla RJ. 2001. Rice-bran products: Phytonutrients with potential applications in preventive and clinical medicine. Drugs Exp Clin Res 27:17-26.

Juliano BO, Bechtel DB. 1985. The rice grain and its gross composition. In: B. O. Juliano, (Ed.), Rice Chemistry and Technology. American Association of Cereal Chemistry, St. Paul, Minnesota, pp. 17-57.

Kahlon TS, Chow FI, Sayre RN. 1994. Cholesterol-lowering properties of rice bran. Cer Foods World 39:99-103. 
Kanauchi O, Larauche M, Taché Y. 2014. Development of Functional Foods (Enzyme-Treated Rice Fiber) from Rice By-products. Wheat and Rice in Disease Prevention and Health, 521-532. ISBN: 9780124017160. Academic Press.

Kedia G, Vázquez JA, Pandiella SS. 2008. Evaluation of the fermentability of oat fractions obtained by debranning using lactic acid bacteria. J Appl Microb 105:1227-1237.

Kedia G, Vázquez JA, Charalampopoulos D, Pandiella SS. 2009. In vitro fermentation of oat bran obtained by debranning with a mixed culture of human fecal bacteria Curr Microb 58:338-342.

Lamberts L, De Bie E, Vandeputte GE, Veraverbeke WS, Derycke V, De Man W, Delcour JA. 2007. Effect of milling on colour and nutritional properties of rice. Food Chem 100:1496-1503.

Langendijk PS, Schut F, Jansen GJ, Raangs GC, Kamphuis GR, Wilkinson MH, Welling GW. 1995. Quantitative fluorescence in situ hybridization of Bifidobacterium spp. with genus-specific 16S rRNA-targeted probes and its application in fecal samples. Appl Environ Microbiol 61:3069-3075.

Lee $\mathrm{KH}$, Rhee $\mathrm{KH}$, Cho $\mathrm{CH}$. 2014. The chemoprotective effect of fermented rice bran on doxorubicin induced toxicity in the rat. Nat Prod Sci 20:29-32.

Likotrafiti E, Tuohy KM, Gibson GR, Rastall RA. 2014. An in vitro study of the effect of probiotics, prebiotics and synbiotics on the elderly faecal microbiota. Anaerobe 27:50-55.

Macfarlane S, Macfarlane GT, Cummings JH. 2006. Review article: prebiotics in the gastrointestinal tract. Alimen Pharma Therap 24:701-714. 
Mandalari G, Nueno Palop C, Tuohy K, Gibson GR, Bennett RN, Waldron KW, Bisignano G, Narbad A, Faulds CB. 2007. In vitro evaluation of the prebiotic activity of a pectic oligosaccharide-rich extract enzymatically derived from bergamot peel. Appl Microbiol Biotech 73:1173-1179.

Manz W, Amann R, Ludwig W, Vancanneyt M, Schleifer KH. 1996. Application of a suite of $16 \mathrm{~S}$ rRNA-specific oligonucleotide probes designed to investigate bacteria of the phylum cytophagaflavobacter-bacteroides in the natural environment. Microbiol 142:1097-1106.

McCartney AL. 2002. Application of molecular biological methods for studying probiotics and the gut flora. Brit J Nutr 88:S29-S37.

Miller GL. 1959. Use of dinitrosalicylic acid reagent for determination of reducing sugar. Anal Chem 31:426-428.

Mohapatra D, Bal S. 2006. Cooking quality and instrumental textural attributes of cooked rice for different milling fractions. J Food Eng. 73:253-259.

Ogué-Bon E, Khoo C, Hoyles L, McCartney A, Gibson G, Rastall RA. 2011. In vitro fermentation of rice bran combined with Lactobacillus acidophilus 14 150B or Bifidobacterium longum 05 by the canine faecal microbiota. FEMS Microbiol Ecol 75:365-376.

Prosky L, Asp NG, Schweizer T, DeVries J, Furda I. 1992. Determination of insoluble and soluble dietary fibre in foods and food products: Collaborative study. JAOAC 75: 360-367.

Pryde SE, Duncan SH, Hold GL, Stewart CS, Flint HJ. 2002. The microbiology of butyrate formation in the human colon. FEMS Microbiol Letters 217:133-139. 
Rycroft CE, Jones MR, Gibson GR, Rastall RA. 2001. A comparative in vitro evaluation of the fermentation properties of prebiotic oligosaccharides. $\mathrm{J}$ Appl Microbiol 91:878-887.

Saman P, Fuciños P, Vázquez JA, Pandiella SS. 2011. Fermentability of brown rice and rice bran for growth of human Lactobacillus plantarum NCIMB 8826. Food Tech Biotech 49:128-132.

Sarbini SR, Kolida S, Deaville ER, Gibson GR, Rastall RA. 2014. Potential of novel dextran oligosaccharides as prebiotics for obesity management through in vitro experimentation. Brit J Nutr 112:1303-1314.

Sharp RN. 1991. Rice: production, processing, and utilization. In: J. L. Klaus, and Kulp, K., (Ed.), Handbook of Cereal Science and Technology. Marcel Dekker, pp. 301-329.

Topping DL, Clifton PM. 2001. Short-chain fatty acids and human colonic function: Roles of resistant starch and nonstarch polysaccharides. Physiol Rev 81:1031-1064.

Tuohy KM, Rouzaud GC, Brück WM, Gibson GR. 2005. Modulation of the human gut microflora towards improved health using prebiotics Assessment of efficacy. Curr Pharm Des 11:75-90.

Velazquez OC, Lederer HM, Rombeau JL. 1996. Butyrate and the colonocyte:Implications for neoplasia. Dig Dis Sci 41:727-739.

Vergara BS. 1991. Rice plant growth and development. In: B. S. Luh, (Ed.), Rice Production. Van Nostrand Reinhold, New York, pp. 13-22.

Zhao G, Nyman M, Jönsson JA. 2006. Rapid determination of short-chain fatty acids in colonic contents and faeces of humans and rats by acidified 
water-extraction and direct-injection gas chromatography. Biomed Chromat 20:674-682.

Yang J, Maldonado-Gómez MX, Hutkins RW, Rose DJ. 2014. Production and in Vitro fermentation of soluble, non-digestible, feruloylated oligo- and polysaccharides from maize and wheat brans. J Agric Food Chem 62:159-166. 


\section{TABLE CAPTIONS}

Table 1. Chemical composition of rice fractions ( $\%$ in $\mathrm{g} / 100 \mathrm{~g}$ of dry fractions).

Table 2. Bacterial populations in small-scale batch cultures using raftilose P95 oligofructose an difference from $10 \mathrm{~h}(p \leq 0.05)$.

Table 3. AUC of SCFA kinetics in faecal batch cultures using raftilose P95 oligofructose and six different rice fractions as substrates. Results are means of three different volunteers \pm SD.

\section{FIGURE CAPTIONS}

Figure 1. The fluorescent cells: Lactobacillus spp. (a), Bifidobacterium spp. (b), Bacteroides spp. (c), Clostridium spp. (d), Eubacterium spp. (e) and Atopobium spp. (f).

Figure 2. Production of the three most important SCFA (acetate, propionate and butyrate) at $24 \mathrm{~h}$ of faecal batch cultures using rice fractions, obtained by debranning, and raftilose P95 oligofructose as control. 
Figure 1

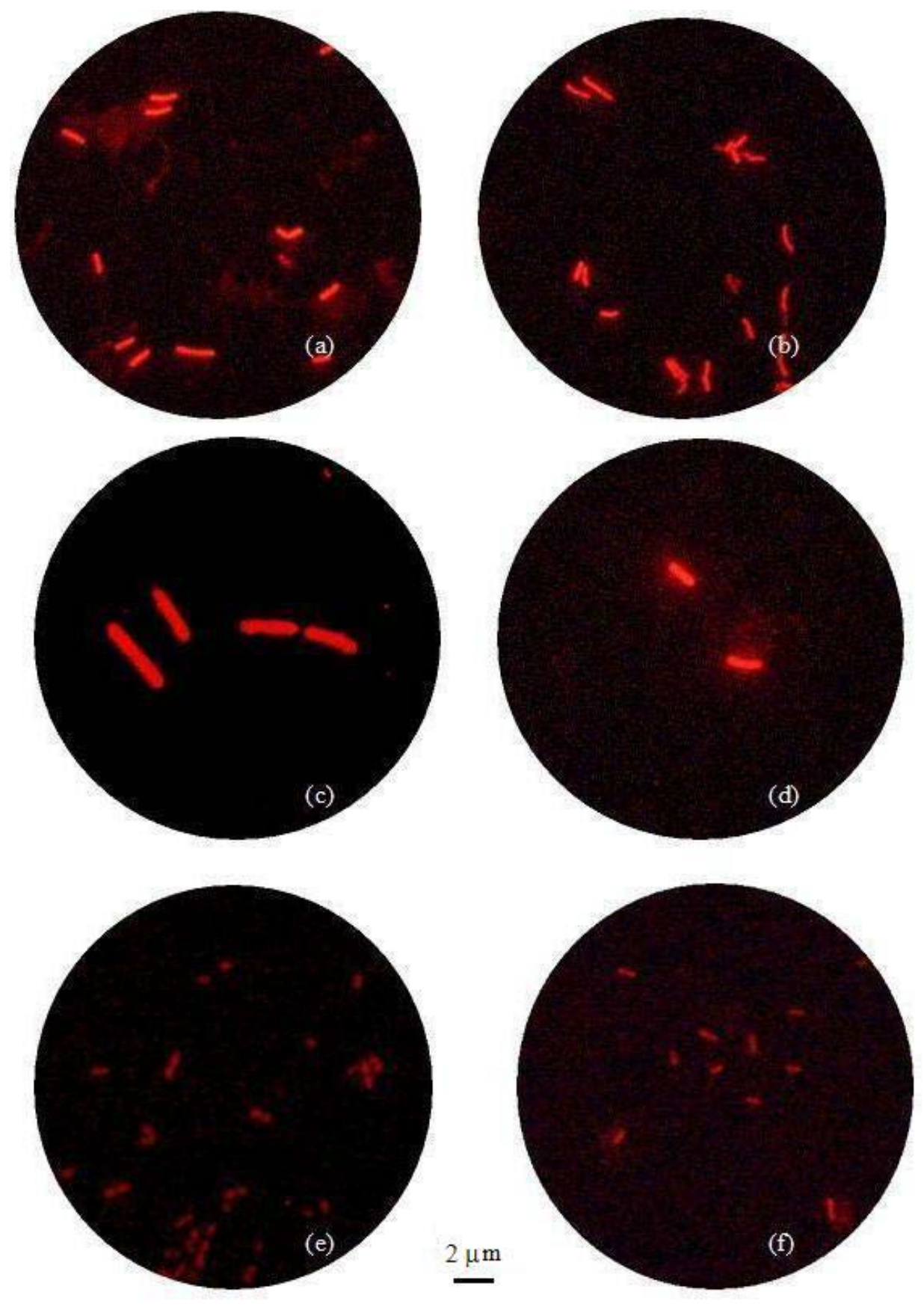


Figure 2

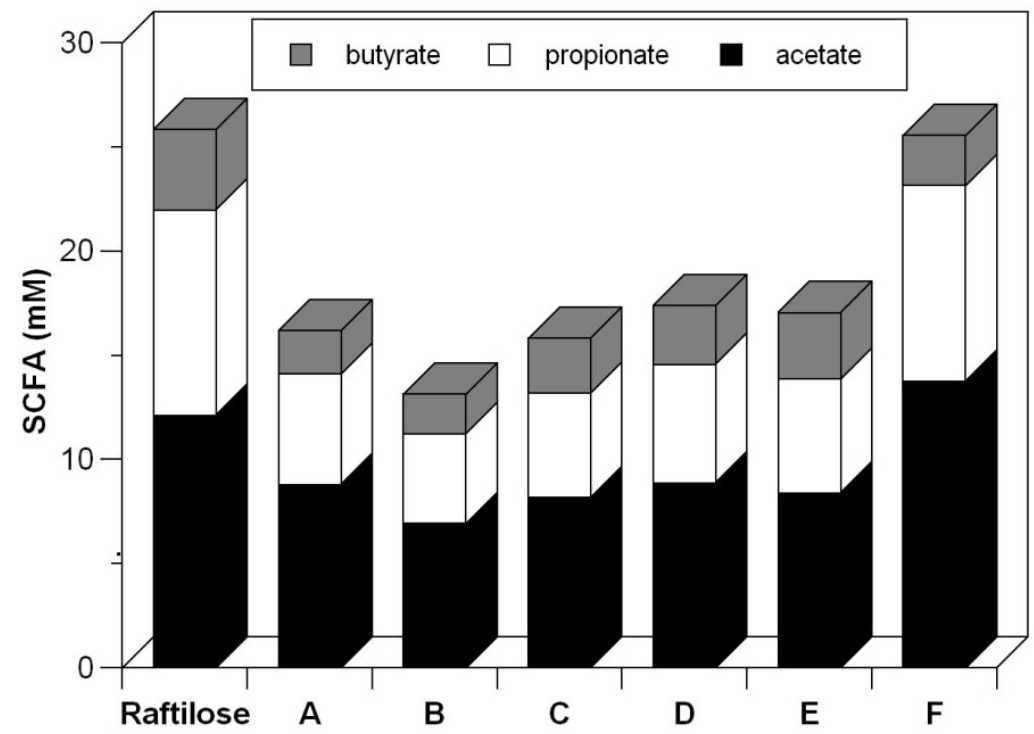


Table 1

\begin{tabular}{|c|c|c|c|c|c|c|}
\hline & & \multicolumn{5}{|c|}{ Chemical Composition } \\
\hline & & $\begin{array}{l}\text { Total Fiber } \\
(\%)\end{array}$ & $\begin{array}{c}\text { Soluble Fiber } \\
\text { (\%) }\end{array}$ & $\begin{array}{c}\text { Insoluble Fiber } \\
\text { (\%) }\end{array}$ & $\operatorname{TRS}\left(\mathrm{g} \mathrm{l}^{-1}\right)$ & $\underset{\left.\mathrm{I}^{-1}\right)}{\operatorname{FAN}(\mathrm{mg}}$ \\
\hline $\begin{array}{l}\text { A: } \quad 0-2.3 \% \\
\text { Fraction }\end{array}$ & Pearling & 34.5 & 1.8 & 32.7 & 1.2 & 8.9 \\
\hline $\begin{array}{l}\text { B: } \quad 2.3-3.8 \% \\
\text { Fraction }\end{array}$ & Pearling & 28.9 & 13.3 & 15.6 & 1.3 & 9.0 \\
\hline $\begin{array}{l}\text { C: } \quad 3.8-5 \% \\
\text { Fraction }\end{array}$ & Pearling & 19.2 & 9.2 & 10.0 & 1.3 & 9.1 \\
\hline $\begin{array}{l}\text { D: } \quad 5-6.3 \% \\
\text { Fraction }\end{array}$ & Pearling & 10.5 & 4.0 & 6.5 & 1.3 & 9.1 \\
\hline $\begin{array}{l}\text { E: } \quad 6.3-7.3 \% \\
\text { Fraction }\end{array}$ & Pearling & 8.2 & 3.1 & 5.1 & 1.1 & 7.4 \\
\hline $\begin{array}{l}\text { F: } \quad 7.3-100 \% \\
\text { Fraction }\end{array}$ & Pearling & 4.6 & 0.9 & 3.7 & 0.7 & 2.9 \\
\hline
\end{tabular}


Table 2

\begin{tabular}{|c|c|c|c|c|c|c|c|c|}
\hline \multirow[b]{2}{*}{ Treatment } & \multirow{2}{*}{$\begin{array}{l}\text { Time } \\
\text { (h) }\end{array}$} & \multicolumn{7}{|c|}{ Bacteria population $\left(\log _{10}\right.$ cells $\left./ \mathrm{ml}\right)$} \\
\hline & & Bifidobacterium & $\begin{array}{l}\text { Lactobacillus } \\
\text { /Enterococcus }\end{array}$ & $\begin{array}{c}\text { E. rectalel } \\
\text { C. coccoides }\end{array}$ & Bacteroides & C. histolyticum & Atopobium & $\begin{array}{l}\text { Total cell } \\
\text { counts }\end{array}$ \\
\hline \multirow{4}{*}{ Raftilose P95 } & 0 & $7.5 \pm 0.1$ & $6.7 \pm 0.1$ & $8.0 \pm 0.2$ & $7.7 \pm 0.1$ & $5.8 \pm 0.2$ & $7.9 \pm 0.3$ & $8.7 \pm 0.1$ \\
\hline & 5 & $8.4 \pm 0.1^{\mathrm{a}}$ & $6.8 \pm 0.2$ & $8.4 \pm 0.1$ & $8.1 \pm 0.3$ & $6.0 \pm 0.2$ & $7.9 \pm 0.3$ & $9.1 \pm 0.1^{\mathrm{a}}$ \\
\hline & 10 & $8.6 \pm 0.1^{\mathrm{a}}$ & $7.0 \pm 0.2$ & $8.7 \pm 0.1^{\mathrm{ab}}$ & $8.5 \pm 0.2^{\mathrm{a}}$ & $5.7 \pm 0.1^{\mathrm{D}}$ & $7.7 \pm 0.2$ & $9.3 \pm 0.1^{a}$ \\
\hline & 24 & $8.8 \pm 0.1^{\mathrm{abc}}$ & $7.2 \pm 0.4$ & $8.9 \pm 0.1^{\mathrm{abc}}$ & $8.7 \pm 0.1^{\mathrm{a}}$ & $5.4 \pm 0.0^{\mathrm{bc}}$ & $7.6 \pm 0.2$ & $9.5 \pm 0.1^{\mathrm{abc}}$ \\
\hline \multirow{4}{*}{ Fraction A } & 0 & $7.6 \pm 0.1$ & $6.7 \pm 0.2$ & $8.0 \pm 0.2$ & $7.7 \pm 0.0$ & $5.9 \pm 0.1$ & $7.9 \pm 0.2$ & $8.7 \pm 0.2$ \\
\hline & 5 & $8.1 \pm 0.4$ & $6.9 \pm 0.4$ & $8.2 \pm 0.1$ & $8.0 \pm 0.2$ & $5.9 \pm 0.2$ & $7.8 \pm 0.2$ & $9.0 \pm 0.1$ \\
\hline & 10 & $8.4 \pm 0.3^{\mathrm{a}}$ & $7.1 \pm 0.5$ & $8.2 \pm 0.0$ & $8.1 \pm 0.2$ & $5.7 \pm 0.2$ & $7.6 \pm 0.1$ & $9.1 \pm 0.2$ \\
\hline & 24 & $8.8 \pm 0.2^{a}$ & $7.3 \pm 0.6$ & $8.3 \pm 0.0$ & $8.2 \pm 0.4$ & $5.6 \pm 0.0$ & $7.4 \pm 0.2^{\mathrm{a}}$ & $9.2 \pm 0.1^{a}$ \\
\hline \multirow{4}{*}{ Fraction B } & 0 & $7.5 \pm 0.1$ & $6.7 \pm 0.2$ & $7.9 \pm 0.1$ & $7.7 \pm 0.1$ & $5.9 \pm 0.1$ & $7.9 \pm 0.2$ & $8.7 \pm 0.2$ \\
\hline & 5 & $8.4 \pm 0.3$ & $6.8 \pm 0.2$ & $8.1 \pm 0.1$ & $8.2 \pm 0.0^{\mathrm{a}}$ & $5.8 \pm 0.1$ & $7.8 \pm 0.2$ & $9.0 \pm 0.1^{\mathrm{a}}$ \\
\hline & 10 & $8.6 \pm 0.3^{\mathrm{a}}$ & $7.2 \pm 0.4$ & $8.1 \pm 0.1$ & $8.3 \pm 0.1^{\mathrm{ab}}$ & $5.6 \pm 0.1$ & $7.7 \pm 0.2$ & $9.2 \pm 0.1^{\mathrm{a}}$ \\
\hline & 24 & $8.8 \pm 0.2^{\mathrm{a}}$ & $7.3 \pm 0.6$ & $8.2 \pm 0.1$ & $8.6 \pm 0.1^{\mathrm{abc}}$ & $5.6 \pm 0.1^{\mathrm{a}}$ & $7.6 \pm 0.1^{\mathrm{a}}$ & $9.2 \pm 0.1^{\mathrm{a}}$ \\
\hline \multirow{4}{*}{ Fraction C } & 0 & $7.6 \pm 0.1$ & $6.7 \pm 0.2$ & $7.9 \pm 0.1$ & $7.7 \pm 0.0$ & $5.9 \pm 0.1$ & $7.9 \pm 0.2$ & $8.7 \pm 0.2$ \\
\hline & 5 & $8.5 \pm 0.2^{a}$ & $7.1 \pm 0.5$ & $8.1 \pm 0.1$ & $8.0 \pm 0.1^{\mathrm{a}}$ & $5.8 \pm 0.1$ & $7.9 \pm 0.2$ & $8.8 \pm 0.1$ \\
\hline & 10 & $8.8 \pm 0.2^{\mathrm{a}}$ & $7.2 \pm 0.6$ & $8.2 \pm 0.0^{\mathrm{a}}$ & $8.2 \pm 0.1^{\mathrm{a}}$ & $5.6 \pm 0.0$ & $7.7 \pm 0.2$ & $9.1 \pm 0.1^{\mathrm{ab}}$ \\
\hline & 24 & $9.0 \pm 0.2^{\mathrm{a}}$ & $7.3 \pm 0.6$ & $8.2 \pm 0.1^{\mathrm{a}}$ & $8.4 \pm 0.2^{\mathrm{a}}$ & $5.6 \pm 0.1^{\mathrm{a}}$ & $7.5 \pm 0.1$ & $9.2 \pm 0.1^{a b}$ \\
\hline \multirow{4}{*}{ Fraction D } & 0 & $7.6 \pm 0.2$ & $6.7 \pm 0.1$ & $7.9 \pm 0.1$ & $7.7 \pm 0.0$ & $5.9 \pm 0.2$ & $8.0 \pm 0.2$ & $8.7 \pm 0.2$ \\
\hline & 5 & $8.3 \pm 0.1^{a}$ & $6.7 \pm 0.0$ & $8.1 \pm 0.1$ & $8.0 \pm 0.1^{\mathrm{a}}$ & $5.8 \pm 0.2$ & $7.9 \pm 0.2$ & $9.0 \pm 0.2$ \\
\hline & 10 & $8.6 \pm 0.2^{a}$ & $6.9 \pm 0.1^{b}$ & $8.4 \pm 0.1^{a}$ & $8.3 \pm 0.1^{\mathrm{ab}}$ & $5.8 \pm 0.4^{\mathrm{b}}$ & $7.8 \pm 0.2$ & $9.2 \pm 0.2^{\mathrm{a}}$ \\
\hline & 24 & $8.8 \pm 0.2^{\mathrm{ab}}$ & $6.9 \pm 0.1^{\mathrm{b}}$ & $8.5 \pm 0.2^{\mathrm{ab}}$ & $8.5 \pm 0.0^{\mathrm{abc}}$ & $5.7 \pm 0.3^{b}$ & $7.8 \pm 0.2$ & $9.3 \pm 0.1^{\mathrm{a}}$ \\
\hline \multirow{4}{*}{ Fraction E } & 0 & $7.5 \pm 0.1$ & $6.7 \pm 0.2$ & $7.9 \pm 0.1$ & $7.7 \pm 0.0$ & $5.9 \pm 0.2$ & $7.9 \pm 0.2$ & $8.7 \pm 0.2$ \\
\hline & 5 & $8.1 \pm 0.2^{\mathrm{a}}$ & $6.8 \pm 0.4$ & $8.3 \pm 0.1^{a}$ & $8.3 \pm 0.3$ & $5.9 \pm 0.2$ & $8.0 \pm 0.2$ & $8.9 \pm 0.2$ \\
\hline & 10 & $8.3 \pm 0.1^{a}$ & $7.0 \pm 0.5$ & $8.6 \pm 0.0^{\mathrm{ab}}$ & $8.6 \pm 0.2^{\mathrm{a}}$ & $5.7 \pm 0.2^{\mathrm{a}}$ & $8.0 \pm 0.1$ & $9.1 \pm 0.1$ \\
\hline & 24 & $8.6 \pm 0.2^{\mathrm{ab}}$ & $7.1 \pm 0.7$ & $8.9 \pm 0.0^{\mathrm{abc}}$ & $8.8 \pm 0.1^{\mathrm{a}}$ & $5.7 \pm 0.2^{\mathrm{a}}$ & $8.0 \pm 0.1$ & $9.2 \pm 0.1^{\mathrm{a}}$ \\
\hline \multirow{4}{*}{ Fraction $\mathrm{F}$} & & $7.5 \pm 0.2$ & $6.6 \pm 0.2$ & $8.0 \pm 0.2$ & $7.7 \pm 0.1$ & $5.9 \pm 0.1$ & $7.9 \pm 0.2$ & $8.7 \pm 0.2$ \\
\hline & 5 & $7.8 \pm 0.2$ & $6.7 \pm 0.2$ & $8.3 \pm 0.1$ & $8.3 \pm 0.2^{\mathrm{a}}$ & $5.9 \pm 0.1$ & $8.0 \pm 0.2$ & $9.0 \pm 0.1$ \\
\hline & 10 & $8.2 \pm 0.1^{\mathrm{a}}$ & $6.7 \pm 0.2$ & $8.6 \pm 0.1^{\mathrm{ab}}$ & $8.7 \pm 0.2^{\mathrm{a}}$ & $5.8 \pm 0.1^{\mathrm{a}}$ & $8.1 \pm 0.0$ & $9.2 \pm 0.2^{\mathrm{a}}$ \\
\hline & 24 & $8.3 \pm 0.2^{\mathrm{a}}$ & $6.9 \pm 0.3$ & $8.9 \pm 0.0^{\mathrm{abc}}$ & $8.9 \pm 0.1^{\mathrm{ab}}$ & $5.7 \pm 0.1^{\mathrm{ab}}$ & $8.2 \pm 0.0$ & $9.4 \pm 0.1^{\mathrm{ab}}$ \\
\hline
\end{tabular}


Table 3

\begin{tabular}{|c|c|c|c|c|c|c|c|c|}
\hline \multirow{2}{*}{ Treatment } & \multicolumn{7}{|c|}{ SCFA (mM h) } & \multirow{2}{*}{$\begin{array}{c}\text { Total SCFA } \\
(\mathrm{mM} \mathrm{h})\end{array}$} \\
\hline & acetic & propionic & i-butyric & n-butyric & i-valeric & n-valeric & n-capronic & \\
\hline Raftilose P 95 & $173.2 \pm 20.5$ & $161.6 \pm 73.2$ & $0.56 \pm 0.49$ & $51.8 \pm 53.0$ & $0.77 \pm 0.49$ & $1.82 \pm 1.48$ & $0.35 \pm 0.36$ & $390.5 \pm 25.8$ \\
\hline Fraction A & $151.6 \pm 32.7$ & $95.2 \pm 38.8$ & $2.07 \pm 0.62$ & $31.5 \pm 8.9$ & $4.14 \pm 1.00$ & $5.69 \pm 6.34$ & $0.22 \pm 0.21$ & $289.9 \pm 8.4$ \\
\hline Fraction B & $133.2 \pm 42.9$ & $87.4 \pm 29.1$ & $1.67 \pm 1.45$ & $32.2 \pm 29.4$ & $3.52 \pm 3.27$ & $6.01 \pm 6.28$ & $0.07 \pm 0.06$ & $264.1 \pm 58.1$ \\
\hline Fraction C & $139.2 \pm 33.8$ & $80.7 \pm 36.0$ & $1.77 \pm 1.06$ & $38.4 \pm 16.6$ & $3.78 \pm 1.77$ & $6.75 \pm 6.19$ & $0.02 \pm 0.02$ & $277.8 \pm 31.1$ \\
\hline Fraction D & $158.1 \pm 35.0$ & $106.7 \pm 46.3$ & $3.20 \pm 0.13$ & $42.8 \pm 22.3$ & $3.05 \pm 0.33$ & $4.25 \pm 3.52$ & $0.33 \pm 0.32$ & $318.4 \pm 31.2$ \\
\hline Fraction E & $151.0 \pm 27.6$ & $102.2 \pm 56.7$ & $1.90 \pm 0.50$ & $49.5 \pm 26.3$ & $3.13 \pm 0.52$ & $7.56 \pm 4.79$ & $0.07 \pm 0.14$ & $315.5 \pm 36.3$ \\
\hline Fraction F & $237.7 \pm 86.7$ & $157.1 \pm 82.5$ & $1.57 \pm 0.18$ & $35.9 \pm 2.4$ & $2.28 \pm 0.43$ & $5.49 \pm 4.93$ & $0.00 \pm 0.00$ & $440.2 \pm 20.5$ \\
\hline
\end{tabular}

